\title{
Leptin and leptin receptor in pig spermatozoa: evidence of their involvement in sperm capacitation and survival
}

\author{
Saveria Aquila ${ }^{1,3}$, Vittoria Rago ${ }^{2}$, Carmela Guido ${ }^{1,3}$, Ivan Casaburi ${ }^{1,3}$, Silvia Zupo ${ }^{1,3}$ \\ and Amalia Carpino ${ }^{2}$ \\ ${ }^{1}$ Department of Pharmaco-Biology, ${ }^{2}$ Department of Cell Biology, Faculty of Pharmacy and ${ }^{3}$ Centro Sanitario, \\ University of Calabria, 87036 Arcavacata di Rende, Cosenza, Italy \\ Correspondence should be addressed to A Carpino at Dipartimento di Biologia Cellulare, Università della Calabria, 87030 \\ Arcavacata di Rende, Cosenza, Italy; Email: am_carpino@yahoo.it
}

\begin{abstract}
Several studies have recently investigated the role of leptin, the adipocyte-secreted hormone, in the growth and reproduction of rodents, humans, and domestic animals. The present study was designed to explore the expression of leptin and its receptor in pig spermatozoa. Successful Western blot evidenced a $16 \mathrm{kDa}$ band for leptin and six isoforms, ranging from 120 to $40 \mathrm{kDa}$, for the leptin receptor. Both leptin and leptin receptor were interestingly located at sperm acrosomal level, suggesting their involvement in the oocyte fertilization events. In fact, both capacitation indexes and acrosin activity were enhanced by leptin, and these effects were reduced by the anti-leptin receptor antibody. Afterwards, we investigated the main transduction pathways regulated by the hormone. Our results showed that, in pig sperm, leptin can trigger the signal transducer and activator of transcription 3, a classical component of cytokine signal transduction pathways, whose expression has not been previously reported in male gamete; in addition it was found constitutively activated. Besides, leptin was able to induce the activation of phosphatidylinositol phosphate kinase 3 and MAP kinase pathways as well as of BCL2, a known antiapoptotic protein. These data address to a role of leptin and its receptor on pig sperm survival. The presence of leptin and its receptor in pig sperm suggests that they, through an autocrine short loop, may induce signal transduction and molecular changes associated with sperm capacitation and survival.

Reproduction (2008) 136 23-32
\end{abstract}

\section{Introduction}

Leptin (LEP) is known to be the hormonal link between energy stores and several vital functions, including food intake and energy homeostasis. It is a $16 \mathrm{kDa}$ adipocytederived hormone that suppresses food intake, stimulates energy expenditure, increases metabolic rate, and ultimately causes loss of body fat (Kamohara et al. 1997, Rossetti et al. 1997, Bouloumie et al. 1998). The effects of LEP as a central satiety agent have been focused on, and its involvement in the regulation of fatness via feed intake was reported. Although LEP was originally thought to act largely via the central nervous system (CNS), recent studies have demonstrated that LEP exerts a wide repertoire of peripheral effects, through direct actions on target tissues. These effects include the stimulation of fatty acid oxidation in adipocytes (Muller et al. 1997, Bouloumie et al. 1998, Lord et al. 1998, Sierra-Honigmann et al. 1998, Zhao et al. 1998) as well as the increase of glucose uptake in skeletal muscle and brown adipose tissue (Kamohara et al. 1997, Yaspelkis et al. 1999).

The pig is emerging rapidly as an important biomedical research model, and whereas genetic influences may impact the degree of similarity between pig and human systems, the regulation of some endocrine and metabolic processes in the pig may be more similar to humans than to rodents (Tsiaoussis et al. 2001, Vilei et al. 2001). LEP plays a key role in the regulation of energy homeostasis and is also linked to the mechanisms controlling reproductive processes. However, very limited data have reported the involvement of LEP in controlling pig reproductive functions at the level of hypothalamus and pituitary. The relationship between nutrition and reproduction in swine has been extensively reviewed (Quesnel \& Prunier 1995, Zurek et al. 1995). Nutrition may influence the reproductive performance by a number of mechanisms, including central effects on gonadotropin secretion (Booth et al. 1994) and local effects on ovarian function (Cosgrove et al. 1992, Booth et al. 1996). According to Zak et al. (1997), the different feeding regimens caused differential sow body weight changes. In pig, nutritional signals, such as LEP, are detected by the CNS and translated, by the neuroendocrine system, into signals that regulate appetite, gonadotropin-releasing hormone release, 
and subsequent luteinizing hormone (LH) secretion. Changes in body weight or nutritional status are characterized by altered adipocyte function, by a reduction of leptin expression in adipose tissue and a decrease in $\mathrm{LH}$ secretion.

In both male and female mice it has been shown that leptin has direct effects on fertility; in fact the hormone is able to reverse the infertility of $o b / o b$ mice lacking the leptin gene (Cunningham et al. 1999). The biological actions of LEP on body weight homeostasis, neuroendocrine function, and fertility are carried out through interactions with its specific obese receptor (OBR, now known as leptin receptor, LEPR) in target tissues. The pattern of leptin receptor expression in the testis is species specific. There are several isoforms of OBR, which are different mainly in the cytoplasmic domain length (Lee et al. 1996, Takaya et al. 1996, Lollmann et al. 1997, Murakami et al. 1997, Bjorbaek et al. 1998, Dieterich \& Lehnert 1998, Yamashita et al. 1998). The OBR, a single membrane-spanning glycoprotein, belongs to the class I cytokine receptor superfamily and shares sequence homologies for interaction with Janus kinase (JAK) as well as STATs (Tartaglia 1997). To date, the human OBR is identified as a full-length OBRb form (Tartaglia et al. 1995) and also as several short forms generated by alternative splicing, OBRa, OBRc, OBRd, OBRf, and OBRe (Bennett et al. 1996, Cioffi et al. 1996, Tartaglia 1997). The hypothalamus is considered the only tissue expressing predominantly the full-length OBR. However, the long form and several short isoforms are expressed in an increasing number of peripheral tissues (Cioffi et al. 1996, Tartaglia 1997, Glasow et al. 1998, Breidert et al. 1999), including liver, heart, kidneys, lungs, small intestine, pituitary cells, testes, ovaries, spleen, pancreas, adrenal gland, and adipose tissue (Margetic et al. 2002). Furthermore, studies on different OBR splice variants indicated that many tissues may contain a heterologous mix of OBR subtypes. OBR mRNA (long form) has been detected in a variety of porcine tissues, including adipose tissue (Lin et al. 2000). Using in situ hybridization techniques, other groups have shown that leptin receptor mRNA is expressed in Sertoli cells of adult rats (Tena-Sempere et al. 2001).

Rodent testis revealed the OBR expression but with a differential cellular site; in fact, the OBR immunoreactivity was confined in Leydig cells of rat but in germ cells of mouse (El-Hefnawy et al. 2000, Caprio et al. 2003). This discrepancy may be due to interspecies difference. LEP and OBR were found in human seminiferous tubules (Soyupek et al. 2005), human seminal plasma (Jope et al. 2003), human sperm (Aquila et al. 2005) and, recently, OBR was also identified in boar sperm (De Ambrogi et al. 2007). In the present study, we investigated LEP and OBR expression in pig sperm, evaluating their potential role on sperm capacitation and survival. Besides, we investigated the main pathways involved in LEP/OBR signaling in pig sperm.

\section{Results}

\section{LEP expression in pig sperm}

To determine whether mRNA for LEP is present in pig spermatozoa, RNA isolated from Percoll-purified sperm was subjected to reverse PCR. The primer sequences were based on the pig gene sequence and the RT-PCR amplification revealed the expected PCR product size of $280 \mathrm{bp}$ (Fig. 1A). This product was sequenced and found to be identical to the classical pig gene sequence.

The presence of LEP protein in pig spermatozoa was also investigated by Western blotting (WB) using an antibody raised against the carboxyl terminus of the protein. One immunoreactive band was observed at $16 \mathrm{kDa}$ in the lysates from pig sperm samples at the same mobility of the adipocyte extract used as positive control (Fig. 1B).

\section{OBR expression in pig sperm}

To evaluate mRNA for OBR in pig spermatozoa, RNA isolated from Percoll-purified sperm was subjected to reverse PCR. The primer sequences were based on the $O B R$ pig gene sequence of the transmembrane region and the RT-PCR amplification revealed the expected PCR product size of $460 \mathrm{bp}$ (Fig. 2A). This product was sequenced and found to be identical to the pig gene sequence considered.

WB of pig sperm extracts showed six different immunoreactive $O B R$ isoforms $(120,90,80,65,60$, and $40 \mathrm{kDa}$ ) (Fig. 2B), such as the WB of pig epididymal tissue used as positive control (Fig. 2B). The bands were not detected by non-immune rabbit serum indicating that these proteins are specific for OBR (Fig. 2B1).

\section{Immunolocalization of LEP and OBR in pig sperm}

An intense red fluorescence localized leptin in the acrosome of pig sperm while the other cellular regions were unlabeled (Fig. 3A). In addition, a brilliant green

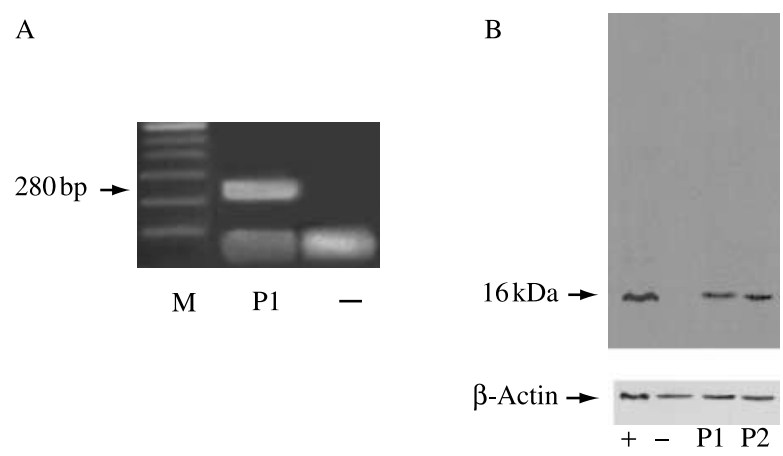

Figure 1 Leptin expression in pig sperm. (A) RT-PCR result in one representative pig sperm sample (lane P1), negative control (lane-), and markers (lane M). (B) Immunoblot of leptin from representative pig sperm samples (lanes P1 and P2), adipocyte cells used as positive $($ lane +$)$, negative (lane-) controls. $\beta$-Actin served as loading control. 

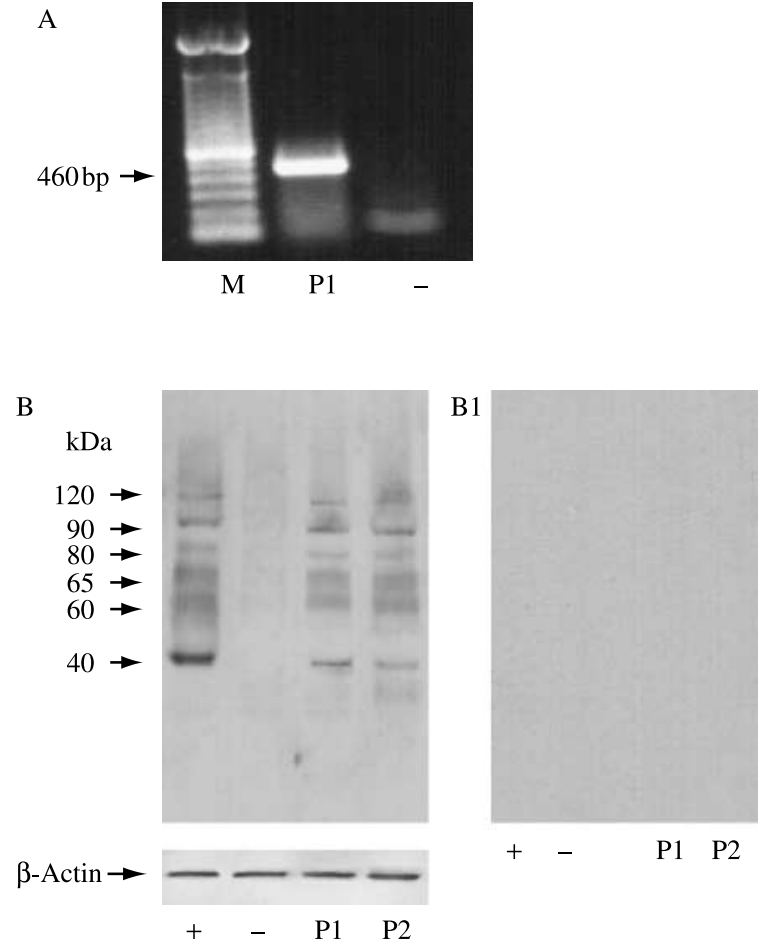

Figure 2 OBR expression in pig sperm. (A) RT-PCR result in one representative pig sperm sample (lane $\mathrm{P} 1$ ), negative control (lane-), and markers (lane M). (B) Immunoblot of OBR from two representative pig sperm samples (lanes-P1, P2), pig epididymis extract (lane + ), and negative control (lane-). (B1) Immunoblot of the negative control (membrane incubated with normal rabbit serum). $\beta$-Actin served as loading control.

light revealed that OBR was confined in the apical portion of sperm acrosome (Fig. 3B). No fluorescent signal was obtained when primary Abs (anti-LEP Ab or anti-OBR Ab) were omitted (Fig. 3 inserts) thus confirming the specificity of the Ab binding.

\section{LEP influences pig sperm capacitation enhancing both cholesterol efflux and protein tyrosine phosphorylation}

One of the early events associated with the capacitation of mammalian spermatozoa is the cholesterol efflux, followed by protein phosphorylation. Our results showed a significant increase in cholesterol efflux upon
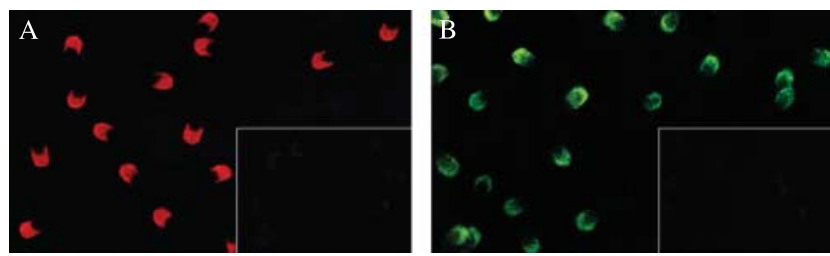

Figure 3 Representative immunofluorescence labeling of leptin and leptin receptor (OBR) in pig spermatozoa. (A) A red intense fluorescence localized leptin in the sperm acrosomal region. (B) A green brilliant light showed OBR in the apical acrosome. Inserts: immunonegative controls. Scale bars: $5 \mu \mathrm{m}$.
1 and 10 nM LEP (Fig. 4A). Protein tyrosine phosphorylation pattern of pig sperm was also induced by 1 and $10 \mathrm{nM}$ LEP treatment (Fig. 4B), but 60 nM LEP did not produce any effect. Further, anti-OBR $A b$ was able to abolish 10 nM LEP effect.

\section{LEP stimulates pig sperm acrosin activity}

Acrosin is a sperm representative acrosomal enzyme. Acrosin activity showed that both 1 and 10 nM LEP were able to stimulate the enzymatic activity, while no effect was observed with 60 nM LEP (Fig. 5). Anti-OBR $\mathrm{Ab}$ combined with $10 \mathrm{nM}$ LEP was able to abolish LEP effect (Fig. 5).

\section{STAT3 is activated by LEP/OBR in pig sperm}

STAT3 is a critical mediator of LEP action. Our results showed the expression of STAT3 (Fig. 6A) in pig sperm

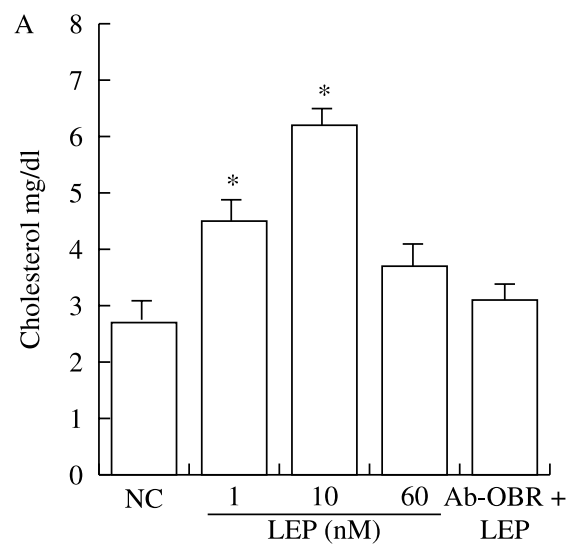

B

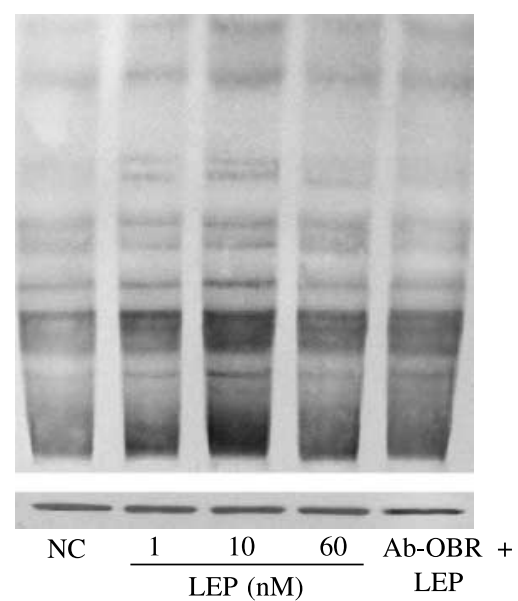

Figure 4 Leptin affects cholesterol efflux and protein tyrosine phosphorylation of pig sperm. Spermatozoa were incubated in the absence (NC) or presence of leptin $(1,10$, and $60 \mathrm{nM})$ as well as in the presence of anti-OBR antibody $+10 \mathrm{nM}$ leptin. (A) Cholesterol in culture medium from pig sperm. Results are presented as mean \pm S.E.M. and are given per $10 \times 10^{6}$ spermatozoa. ${ }^{*} P<0.05$ versus control. (B) Western blot analysis of protein tyrosine phosphorylation from sperm lysates. 


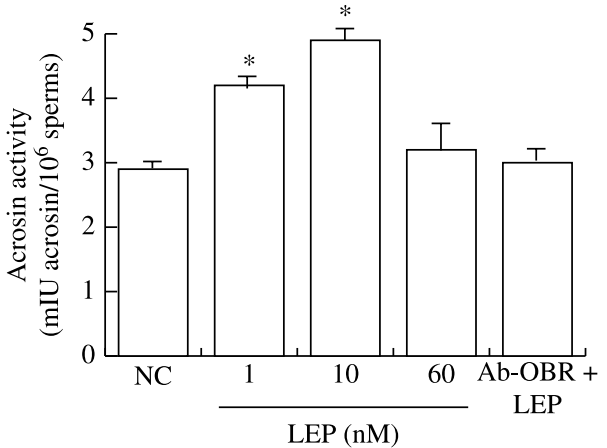

Figure 5 Leptin affects acrosin activity of pig sperm. Spermatozoa were incubated in the absence (NC) or presence of leptin (1, 10, and $60 \mathrm{nM})$ as well as in the presence of anti-OBR antibody $+10 \mathrm{nM}$ leptin. Values are mean \pm s.E.M. ${ }^{*} P<0.05$ versus control.

and that it is constitutively activated (phosphorylated) (Fig. 6B). Furthermore, 1 and $10 \mathrm{nM}$ LEP treatments induced a significant increase in STAT3 activation that was reversed by the anti-OBR Ab (Fig. 6B and C).

A

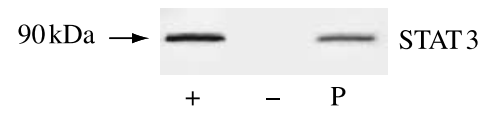

B

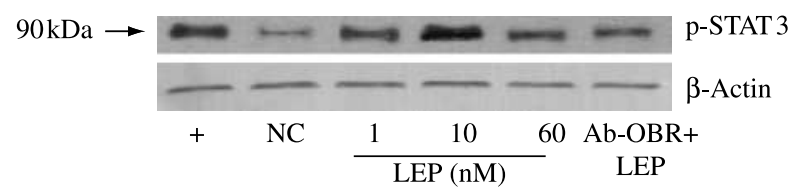

$\mathrm{C}$

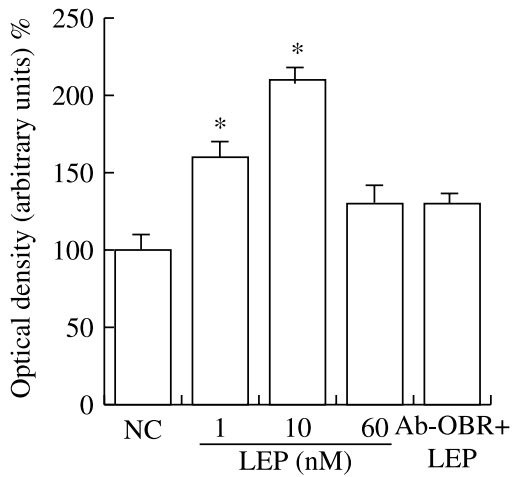

Figure 6 Western blot analysis of STAT3 from one representative pig sperm lysate. (A) Immunoblot of STAT3 in the pig sample (lane P), MCF7 used as positive (lane + ) and negative (lane-) controls. (B) p-STAT3 band in sperm incubated in the absence (lane NC) or presence of leptin $(1,10$, and $60 \mathrm{nM})$ as well as in the presence of antiOBR antibody $+10 \mathrm{nM}$ leptin (Ab OBR + LEP). MCF7 cell lines were used as positive controls (lane + ). $\beta$-Actin served as loading control. (C) Band intensities were evaluated in term of arbitrary densitometric units. Values are as mean \pm s.E.M. ${ }^{*} P<0.05$ versus control.

\section{ERK1/2 is activated by LEP/OBR in pig sperm}

Components of the ERK family of MAPK are involved in sperm motility and capacitation. Our results showed the expression of ERK1/2 in pig sperm (Fig. 7A) and evidenced that LEP, through its receptor, is able to activate ERK1/2 (Fig. 7B and C). The maximal effect was observed with 1 and 10 nM LEP, while 60 nM LEP did not result in further activation (Fig. $7 \mathrm{~B}$ and $\mathrm{C}$ ).

\section{LEP/OBR signaling modulates pig sperm survival}

Our data revealed that pig sperm express BCL2, a key protein in sperm survival signaling (Fig. 8A). Furthermore, leptin induced the Serine 70 phosphorylation of BCL2, necessary for its full antiapoptotic function, and this effect was inhibited by the anti-OBR $\mathrm{Ab}$ (Fig. $8 \mathrm{~B}$ and $\mathrm{C}$ ).

$\mathrm{PI} 3-\mathrm{K}$ plays also an important role in sperm survival, and its main downstream effector is the Akt. Our results showed the expression of Akt (Fig. 8D) and phosphorylated Akt (S473 and T308 phosphorylations) in pig sperm (Fig. 8E). In addition, LEP induced an increase in the kinase phosphorylation, which was reduced by using anti-OBR $\mathrm{Ab}$ (Fig. 8E and F). The specific PI3-K inhibitor, $10 \mu \mathrm{M}$

A

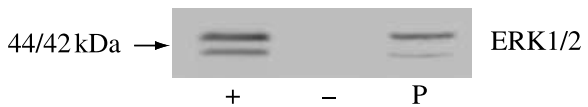

B
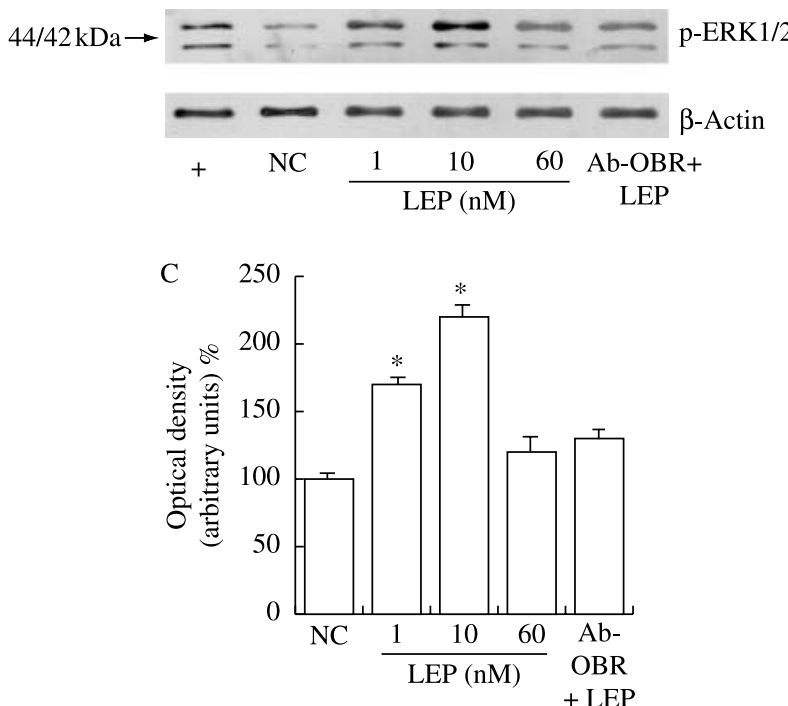

Figure 7 Western blot analysis of ERK1/2 from one representative pig sperm lysate. (A) Immunoblot of ERK1/2 in the pig sample (lane P), MCF7 used as positive (lane + ) and negative (lane-) controls.

(B) p-ERK1/2 band in spermatozoa incubated in the absence (lane NC) or presence of leptin $(1,10$, and $60 \mathrm{nM})$ as well as in the presence of antiOBR antibody $+10 \mathrm{nM}$ leptin (Ab OBR + LEP). MCF7 cell lines were used as positive controls (lane + ). $\beta$-Actin served as loading control.

(C) Band intensities were evaluated in term of arbitrary densitometric units. Values are as mean \pm S.E.M. ${ }^{*} P<0.05$ versus control. 

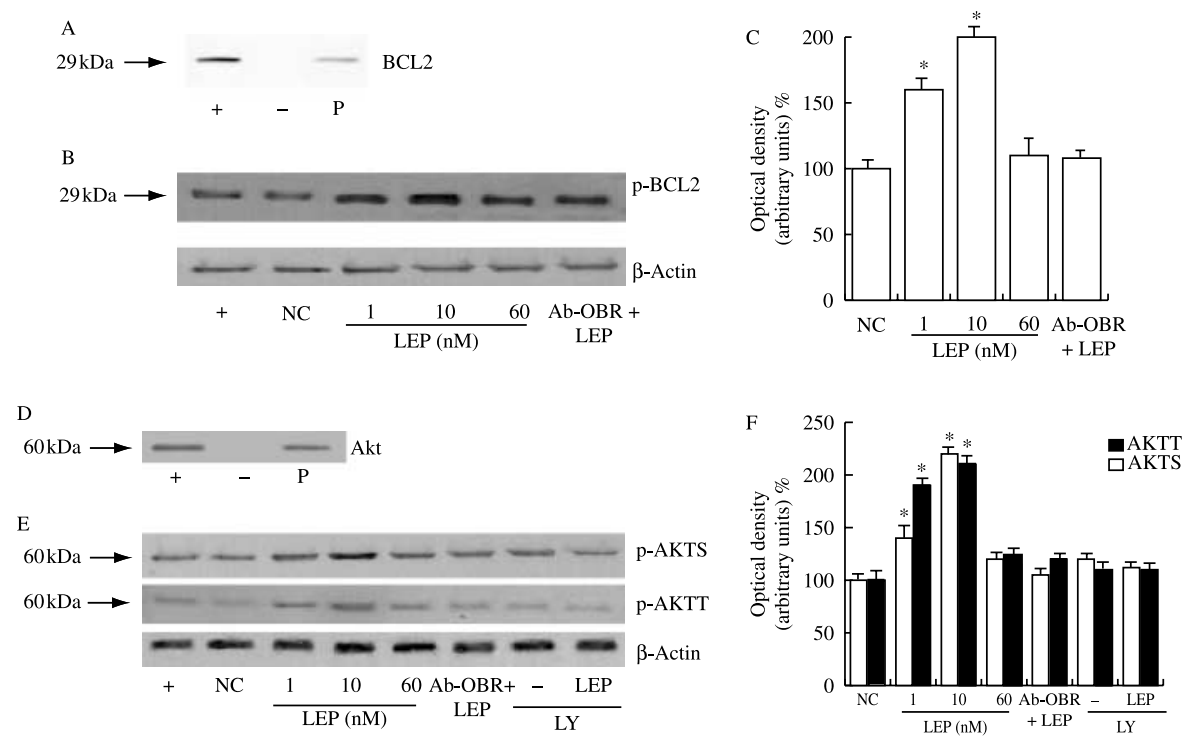

Figure 8 Western blot analysis of BCL2 and Akt from one representative pig sperm lysate. (A and D) Immunoblots of BCL2 and Akt, in the pig sample (lane P), MCF7 used as positive (lane + ) and negative (lane - ) controls. (B) p-BCL2 band when sperm cells were incubated in the absence (lane $\mathrm{NC})$ or presence of leptin $(1,10$, and $60 \mathrm{nM})$ as well as in the presence of antiOBR antibody + $10 \mathrm{nM}$ leptin (Ab OBR + LEP). (E) p-AKTS (Akt ser) and p-AKTT (Akt thr) bands in sperm incubated in the absence (lane NC) or presence of leptin (1, 10 , and $60 \mathrm{nM}$ ) as well as in the presence of anti-OBR antibody $+10 \mathrm{nM}$ leptin (Ab OBR + LEP) or LY294002 (LY). (C and F) Band intensities were evaluated in terms of arbitrary densitometric units. Values are as mean \pm S.E.M. ${ }^{*} P<0.05$ versus control. $\beta$-Actin served as loading control.
LY294002, abolished LEP-induced Akt phosphorylations (Fig. 8E and F), confirming the PI3K/Akt activation. Also in the PI3K/Akt pathway, the $60 \mathrm{nM}$ LEP did not induce a significant effect (Fig. 8E and F).

\section{Discussion}

In recent years, it has been suggested that LEP is a metabolic signal to the reproductive system (Barash et al. 1996). To date, the mechanisms by which LEP regulates reproductive function remain to be determined. LEP and OBR were recently found in human sperm (Jope et al. 2003, Aquila et al. 2005) and the OBR in boar sperm (De Ambrogi et al. 2007). However, LEP and its signaling in the male gamete function are still unknown in nonhuman species. In the present study, we have investigated the presence of LEP and OBR in pig sperm evaluating, for the first time, their potential action on capacitation, and sperm survival. The main aim of our study was also to identify the potential signaling molecules that are set in motion by LEP in pig sperm.

First, we have demonstrated the presence of LEP and OBR in pig sperm at different levels: mRNA expression, protein expression, and immunolocalization. Pig sperm LEP, as protein, was evidenced at the same size as human sperm leptin (Aquila et al. 2005). In addition, we detected the $L E P$ and $O B R$ mRNAs in pig perm. Other authors reported the presence of different mRNAs in mammalian ejaculated spermatozoa; however, the significance of mRNA in these cells is currently under investigation (Miller 2000, Andò \& Aquila 2005). WB analysis revealed six different OBR isoforms, among these the $120 \mathrm{kDa}$ band is consistent with the OBRb isoform while the other bands could correspond to short isoforms. A partially similar pattern of OBR has been detected in the adult mouse testis (El-Hefnawy et al. 2000), but the pattern of OBR expression is species specific.

Interestingly, immunofluorescence assays localized both LEP and OBR exclusively at acrosomal level of pig sperm. Spermatozoa are highly polarized cells, thus they compartmentalize specific metabolic and signaling pathways where they are necessary. Therefore, a role of LEP/OBR in the events leading to the sperm becoming able to fertilize the oocyte can be hypothesized. Our data on OBR agree with the De Ambrogi et al. (2007) findings, showing the receptor prevalently located on the acrosome of boar sperm, whereas in human sperm the receptor was visualized at the tail (Jope et al. 2003). These differences may be due to sample management or they could be species specific. Despite the use of the same antibody, the different leptin localization in human and pig sperm is particularly intriguing. In fact, the hormone was specifically compartmentalized in the equatorial segment and in the mid-piece of human sperm (Aquila et al. 2005). We can only hypothesize that leptin is differently involved in the regulation of sperm events in the two species.

In order to fertilize oocyte in the female genital tract, the mammalian spermatozoa must undergo the capacitation process that is a prerequisite for the acrosome reaction. Capacitation induces various biochemical and biophysical changes in the sperm plasma membrane, such as the efflux of cholesterol (Visconti et al. 1999a, 1999b, Shadan et al. 2004). Cholesterol efflux from spermatozoa destabilizes lipid raft structures in the plasma membrane initiating the protein phosphorylation and the acquisition of a capacitated status. Tyrosine phosphorylation of sperm proteins during capacitation has been reported in mouse, human, bull, hamster (Visconti et al. 1995, Leclerc et al. 1996, GalantinoHomer et al. 1997), and also in pig (Kalab et al. 1998, 
Flesch et al. 1999, Tardif et al. 2003). Our data have shown that, in pig sperm, leptin increased cholesterol efflux, protein tyrosine phosphorylation, and the acrosin activity. Therefore, LEP, through its receptor, appears to affect both capacitation and acrosome reaction, suggesting its role in the acquisition of fertilizing ability of pig sperm.

The signaling events, derived from LEP binding to its receptor, have been recently investigated at biochemical and molecular level. The JAK/STAT pathway is one of the main signaling cascades activated by LEP (Thomas 2004). The OBR, which belongs to the class I cytokine receptor superfamily, binds cytoplasmic kinases, mainly JAK2 (Ghilardi \& Skoda 1997). Activated JAK2 auto-phosphorylates numerous tyrosine residues and, at the same time, it phosphorylates tyrosine residues on the functional OBR. Then the phosphorylated intracellular domain of the receptor provides a binding site for STAT proteins (particularly STAT3), which are activated and translocated to the nucleus where they stimulate transcription of target genes. In our study, for the first time, we have demonstrated that STAT3 is expressed in the pig sperm, it is constitutively activated, and its phosphorylation increases following LEP binding to its receptor. Therefore, we provide new information to indicate that LEP can stimulate the JAK-STAT pathway in pig sperm.

Since capacitation is a crucial step in the acquisition of sperm fertilizing ability, it is likely controlled by redundant mechanisms, with cross-talks between different pathways (de Lamirande et al. 1997, Leclerc et al. 1998). The components of the extracellular signalregulated kinase family of MAPK have been detected in spermatozoa affecting their motility and capacitation (Naz et al. 1992, Luconi et al. 1998, de Lamirande \& Gagnon 2002). Our results have shown the expression of ERK1/2 in pig male gamete and have evidenced that LEP, through its receptor, was able to positively activate ERK1/2, suggesting that MAPK-dependent processes are involved in the hormone action.

Several pathways are also activated by JAKs including $\mathrm{PI3K} / \mathrm{Akt}$. PI3K plays an important role in the survival and metabolism of somatic and sperm cells (Fisher et al. 1998, Luconi et al. 2001, Aquila et al. 2004, 2005, Aparicio et al. 2006). The PI3K main downstream effector is the Akt, identified as a serine/threonine protein kinase, which was found in human ejaculated spermatozoa (Aquila et al. 2004) and in boar spermatozoa (Aparicio et al. 2006).

From our results it emerges that $\mathrm{PI} 3 \mathrm{~K}$ and Akt are implicated in mediating LEP signals in pig sperm, suggesting that this hormone may be involved in sperm survival. Concomitantly, BCL2 (Ito et al. 1997), a key protein in survival signaling, is enhanced upon LEP exposure and this effect was reduced by the anti-OBR Ab. Previous works have shown that LEP attenuates apoptosis of different cell types, such as osteoblasts, granulosa cells, and pancreatic islet cells (Almong et al.
2001, Okuya et al. 2001, Gordeladze et al. 2002). Moreover, recently, LEP has been found to inhibit stressinduced apoptosis of T lymphocytes in vivo (Fujita et al. 2002). Data presented here clearly demonstrate that LEP, by inducing the phosphorylation of classical key survival proteins, such as ERK1/2, PI3K, Akt, and BCL2, aids the pig sperm survival process.

It is important to point out that in all our experiments, we obtained different responses by using low or high LEP doses; in fact $1 \mathrm{nM}$ and $10 \mathrm{nM}$ were stimulatory, whereas the higher LEP concentration seemed to be ineffective (similar to the control). The outcome of signaling activation can depend on differences in ligand concentration as it was demonstrated in human sperm (Aquila et al. 2005). Besides, recently it was hypothesized that the net effect of LEP upon male reproductive function may depend on its circulating level (Caprio et al. 2001, Tena-Sempere \& Barreiro 2002). The effect obtained with the higher LEP dose may be also due to the downregulation or internalization of the OBR depending on the ligand concentration as previously demonstrated (Uotani et al. 1999).

In addition, it has been demonstrated that pig seminal plasma contains a significant amount of LEP, which decreases considerably in the follicular fluid (Lackey et al. 2002). As sperm leave seminal plasma during their transit in the female reproductive tract, they are exposed to decreased LEP concentrations. From our results, it may be speculated that the high LEP in seminal plasma may contribute to maintain sperm in a quiescent metabolic condition. Instead, the low LEP concentrations in the pig female reproductive tract (Gregoraszczuk et al. 2004) secretions could contribute to sperm activation, by facilitating their capacitation and acquisition of fertilizing ability.

Fatness in pigs has economical importance due to market incentives for the production of lean pork and also because elevated fatness increases feed costs. LEP was identified as a metabolic signal affecting central regulation of reproduction in the pig. Our data have shown that this hormone affects pig sperm acquisition of fertilizing ability. Therefore, further studies, addressed to the knowledge of the balance between local and systemic leptin, will clarify whether the manipulation of LEP concentration, as a strategy to alter body composition, may affect pig reproduction.

\section{Materials and Methods}

\section{Chemicals}

BSA protein standard, Laemmli sample buffer, pre-stained molecular weight marker, Percoll (colloidal PVP coated silica for cell separation), sodium bicarbonate, dimethyl sulfoxide, Earle's balanced salt solution, triethanolamine buffer, $\mathrm{MgCl}_{2}$, propidium iodide, LY294002 (PI3K inhibitor), and all other chemicals were purchased from Sigma. Recombinant porcine leptin was purchased from Protein Laboratories Rehovot 
(Rehovot, Israel) and acrylamide bisacrylamide was from Labtek Eurobio (Milan, Italy). Triton X-100, ECL Plus WB detection system, Hybond ECL were purchased from Amersham Pharmacia Biotech. Antibodies (Abs) polyclonal rabbit anti-leptin (A-20), rabbit anti-OBR (H-300), rabbit anti-pAkt1/Akt2/Akt3 (Ser473), rabbit anti-p-Akt1/Akt2/Akt3 (Thr308), rabbit anti-phosphotyrosine (PY99), mouse ant-psignal transducer and activator of transcription-3 p-STAT3 (B-7), peroxidase-coupled anti-rabbit, and FITC/Texas Red conjugated anti-rabbit IgG were from Santa Cruz Biotechnology (Heidelberg, Germany). Rabbit anti-p-BCL2 and p-ERK1/2 (p42/44 kDa) Abs were from Cell Signaling (Milan, Italy). Cholesterol-oxidase (CHOD)-peroxidase (POD) enzymatic colorimetric kit was from Inter-Medical (Biogemina Italia Srl, Catania, Italy). Total RNA Isolation System kit, enzymes, buffers, nucleotides $100 \mathrm{bp}$ ladder used for RT-PCR were purchased from Promega. Moloney murine leukemia virus (M-MLV) was from Gibco-Life Technologies Italia. Oligonucleotide primers were made by Invitrogen.

\section{Animals and semen samples}

The investigation has been conducted on semen from seven fertile male pigs (Sus scrofa domestica, Large White) kept at the 'Swine Artificial Insemination Centre' (Rende, Cosenza, Italy). The animals were 24 to 30-month old and their weights were from 280 to $320 \mathrm{~kg}$. Individual fresh ejaculates were collected by the gloved-hand method and filtered immediately by Universal Semen bags (Minitub, Tiefenbech, Germany). Semen was transported within half an hour to the laboratory, diluted 1:10 with TBS buffer, and centrifuged on a discontinuous Percoll density gradient ( $72 \% / 90 \%)$ to remove bacteria and debris (Kuster et al. 2004). Epididymides were obtained from two out of the seven animals after castration at local animal hospitals. All surgical procedures followed approved guidelines for the ethical treatment of animals. Epididymides were brought immediately to the laboratory, then were carefully dissected, freed from sperm, homogenized, and lysed for WB analysis.

\section{Evaluation of sperm viability}

Viability of pig sperm was assessed using the DNA-specific fluorochrome PI. Sperm suspension $\left(1 \times 10^{6} \mathrm{ml}\right)$ was exposed to $\mathrm{PI}(12 \mu \mathrm{mol} / \mathrm{l})$ for $5 \mathrm{~min}$ at room temperature. Then spermatozoa were fixed by adding $1 \mathrm{ml}$ of $12.5 \%(\mathrm{w} / \mathrm{v})$ paraformaldehyde in $0.5 \mathrm{~mol}$ Tris/l $(\mathrm{pH} \mathrm{7.4)}$ and the slides were immediately examined under an epifluorescence microscope (Olympus BX41) observing a minimum of 200 spermatozoa $\times$ slide $(100 \times$ objective).

\section{Sample treatments}

Percoll-purified sperm were washed with unsupplemented Earle's medium (uncapacitating medium) and were incubated for $30 \mathrm{~min}$ at $39^{\circ} \mathrm{C}$ and $5 \% \mathrm{CO}_{2}$ without (control) or with increasing concentrations of $\operatorname{LEP}(1,10$, and $60 \mathrm{nM})$. These doses were chosen on the basis of physiological concentrations to reproduce the environment of the sperm journey. Some cells were also pretreated (15 min) with the inhibitor, LY294002, or with the anti-OBR Ab (autocrine blockage). No adverse effects among the different treatments have been observed on pig sperm viability.

Then, samples were centrifuged ( $3000 \mathrm{~g} \times 5 \mathrm{~min}$ ) using the upper phase for further determinations and sperm pellet for WB analysis.

\section{Western blot analysis of sperm proteins}

WB analysis was used to identify LEP and OBR in sperm samples obtained from all the seven animals. Sperm samples were washed twice with Earle's balanced salt solution (uncapacitating medium) and then centrifuged for $5 \mathrm{~min}$ at $5000 \mathrm{~g}$. The pellet was resuspended in lysis buffer as previously described (Aquila et al. 2002). Equal amounts of proteins (80 $\mu \mathrm{g}$ ) were boiled for $5 \mathrm{~min}$, separated by $10 \%$ PAGE, transferred to nitrocellulose sheets, and probed with an appropriate dilution of the (indicated) specific Ab. The bound of the secondary antibody was revealed with the ECL Plus WB detection system according to the manufacturer's instructions. The negative control was performed using a sperm lysate that was immunodepleted of LEP or OBR (i.e., lysates pre-incubated with anti-leptin $\mathrm{Ab}$ or anti-OBR Ab for $1 \mathrm{~h}$ at room temperature and immunoprecipitated with Protein A/G-agarose).

To further validate the results for OBR, as negative control, non-immune rabbit serum, instead of the first $A b$, was used at the same dilution ratio (1:1000). Epididymal extract was used as pig control tissue.

WB was also performed to identify STAT3, BCL2, ERK1/2, Akt1/Akt2 in pig sperm extracts and evaluate the cell signaling induced by LEP (p-Akt1/Akt2/Akt3, p-STAT3, p-BCL2, and $p$-ERK1/2). MCF7 cell lines were used as positive controls while negative controls were performed as indicated above. The blots were stripped (glycine $0.2 \mathrm{M}(\mathrm{pH} 2.6)$ for $30 \mathrm{~min}$ at room temperature) and reprobed with anti- $\beta$-actin $\mathrm{Ab}$ as loading control.

The experiments were repeated four times for each sample.

\section{RNA isolation, reverse transcriptase-PCR (RT-PCR)}

Total RNA was isolated from pig spermatozoa purified as previously described (Aquila et al. 2002). Before RT-PCR, RNA was incubated with RNase-free DNase (DNase) I in singlestrength reaction buffer at $37^{\circ} \mathrm{C}$ for $15 \mathrm{~min}$. This was followed by heat inactivation of DNase I at $65^{\circ} \mathrm{C}$ for $10 \mathrm{~min}$. Two micrograms of DNase-treated RNA samples were reverse transcribed by $200 \mathrm{IU}$ M-MLV reverse transcriptase in a reaction volume of $20 \mu \mathrm{l}(0.4 \mu \mathrm{g}$ oligo-dT, $0.5 \mathrm{mM}$ deoxy-NTP, and 24 IU RNasin) for $30 \mathrm{~min}$ at $37^{\circ} \mathrm{C}$, followed by heat denaturation for $5 \mathrm{~min}$ at $95^{\circ} \mathrm{C}$. PCR amplification of cDNA was performed with $2 \mathrm{U}$ of Taq DNA polymerase, 50 pmol primer pair for both LEP and OBR in $10 \mathrm{mM}$ Tris- $\mathrm{Hcl}(\mathrm{pH}$ 9.0) containing $0.1 \%$ Triton $\mathrm{X}-100$, $50 \mathrm{mM} \mathrm{KCl}, 1.5 \mathrm{mM} \mathrm{MgCl}$, and $0.25 \mathrm{mM}$ each dNTP. The applied PCR primers and the expected lengths of the resulting PCR products are the following: 5'ATTCCTGGCTTGGCCC $3^{\prime}$ and $5^{\prime}$ AAGGCAGACTGGTGAGGATCTGTT $3^{\prime}$ for LEP with a product size of $248 \mathrm{bp} ; 5^{\prime}$ ACTTCCTCTTGCCTGCTGGAATCT $3^{\prime}$ and 5' GACACAGGCACATGGCATTCACAA $3^{\prime}$ for OBR with a 
product size $460 \mathrm{bp}$. Cycling conditions were: $95^{\circ} \mathrm{C}$ for $1 \mathrm{~min}$, $55^{\circ} \mathrm{C}$ for $1 \mathrm{~min}, 72^{\circ} \mathrm{C}$ for $2 \min$ for LEP; $95^{\circ} \mathrm{C}$ for $1 \mathrm{~min}, 52{ }^{\circ} \mathrm{C}$ for $1 \mathrm{~min}, 72{ }^{\circ} \mathrm{C}$ for $2 \mathrm{~min}$ for OBR. For all PCR primer amplifications, negative RT-PCR was performed without M-MLV reverse transcriptase. The PCR-amplified products were subjected to electrophoresis in $2 \%$ agarose gels stained with ethidium bromide and visualized under u.v. transillumination.

\section{Immunofluorescence assay}

Following Percoll separation, sperm cells were rinsed three

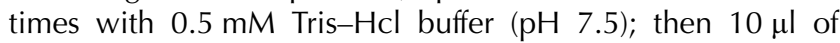
concentrated cell suspension was added to $250 \mu \mathrm{l}$ drop of warm $\left(37^{\circ} \mathrm{C}\right)$ TBS and allowed to settle onto slides in a humid chamber. The overlying solution was carefully pipetted off and replaced by absolute methanol for $7 \mathrm{~min}$ at $-20^{\circ} \mathrm{C}$. After methanol removal, sperm cells were washed in TBS, containing $0.1 \%$ Triton X-100 and were treated for immunofluorescence.

Leptin and OBR stainings were carried out, after blocking with normal goat serum (10\%), using anti-leptin (1:100) and anti-OBR $(1: 100)$ as primary Abs, followed by anti-rabbit IgG Texas Redconjugated/FITC-conjugated Abs (1:200) respectively. Sperm cells incubated without the primary Abs were utilized as negative controls. The slides were immediately examined under an epifluorescence microscope (Olympus BX41), observing a minimum of 200 spermatozoa $\times$ slide $(100 \times$ objective $)$.

\section{Measurement of cholesterol in the sperm culture medium}

Cholesterol was measured (in duplicate) in the incubation medium from pig spermatozoa obtained from all the seven animals. The CHOD-POD enzymatic colorimetric method was used according to the manufacturer's instructions. Sperm samples, washed twice with uncapacitating medium, were incubated in the same medium (control, NC) for $30 \mathrm{~min}$ at $39{ }^{\circ} \mathrm{C}$ and $5 \% \mathrm{CO}_{2}$. Other samples were incubated in the presence of 1, 10, and 60 nM LEP concentrations. Some samples were incubated with anti-OBR Ab combined with $10 \mathrm{nM}$ LEP. At the end of the sperm incubation, the culture media were recovered by centrifugation, lyophilized, and subsequently dissolved in $1 \mathrm{ml}$ of the buffer reaction. The samples were incubated for $10 \mathrm{~min}$ at room temperature and then the cholesterol content was measured with the spectrophotometer at $505 \mathrm{~nm}$. Cholesterol standard used was $200 \mathrm{mg} / \mathrm{dl}$. The limit of sensitivity for the assay was $0.05 \mathrm{mg} / \mathrm{dl}$. Inter- and intra-assay variations were $0.71 \%$ and $0.57 \%$ respectively.

The experiments were repeated four times for each sample.

\section{Acrosin activity assay}

Acrosin activity was assessed by the method of Glogowski et al. (1998). Briefly, sperm samples from all the seven animals were washed in Earle's medium and centrifuged at $800 \mathbf{g}$ for $20 \mathrm{~min}$, then they were resuspended (final concentration of $100 \times 10^{3} \mathrm{sperm} / \mathrm{ml}$ ) in different tubes containing no treatment (control) or the indicated treatments (experimental). One milliliter of substrate-detergent mixture $(23 \mathrm{mmol} / \mathrm{l} \mathrm{N}$ alphabenzoyl-DL-arginine p-nitroanilide in DMSO and $0.01 \%$ Triton
$\mathrm{X}-100$ in $0.055 \mathrm{~mol} / \mathrm{l} \mathrm{NaCl}, 0.055 \mathrm{~mol} / \mathrm{l}$ HEPES (pH 8.0) respectively) was added for $1 \mathrm{~h}$ at room temperature. After incubation, $0.5 \mathrm{~mol} / \mathrm{l}$ benzamidine was added $(0.1 \mathrm{ml})$ to each of the tubes and then they were centrifuged at $1000 \mathrm{~g}$ for $30 \mathrm{~min}$. The supernatants were collected and the acrosin activity measured spectrophotometrically at $410 \mathrm{~nm}$. In this assay, the total acrosin activity is defined as the amount of the active (non-zymogen) acrosin associated with sperm plus the amount of active acrosin that is obtained by pro-acrosin activable. The acrosin activity was expressed as $\mathrm{mIU} / 10^{6}$ sperms. The experiments were repeated four times for each sample.

\section{Statistical analysis}

Data, presented as mean \pm s.E.M., were evaluated by the oneway ANOVA. The differences in mean values were calculated at a significance level of $P \leq 0.05$.

\section{Acknowledgements}

Our special thanks to Dr Vincenzo Cunsulo (Biogemina Italia Srl, Catania, Italy). This work was supported by MURST 2006 (Ex-60\%). The authors declare that there is no conflict of interest that would prejudice the impartiality of this scientific work.

\section{References}

Almong B, Gold R, Tajima K, Dantes A, Salim K, Rubistein M, Barkan D, Homburg R, Lessing JB, Nevo N et al. 2001 Leptin attenuates follicular apoptosis and accelerates the onset of puberty in immature rats. Molecular and Cellular Endocrinology 183 179-191.

De Ambrogi M, Spinaci M, Galeati G \& Tamanini C 2007 Leptin receptor in boar spermatozoa. International Journal of Andrology 30 458-461.

Andò S \& Aquila S 2005 Arguments raised by the recent discovery that insulin and leptin are expressed in and secreted by human ejaculated spermatozoa. Molecular and Cellular Endocrinology 21 245-246.

Aparicio IM, Bragado MJ, Gil MC, Garcia-Herreros M, GonzalezFernandez L, Tapia JA \& Garcia-Marin LJ 2006 Phosphatidylinositol 3-kinase pathway regulates sperm viability but not capacitation on boar spermatozoa. Molecular Reproduction and Development $\mathbf{7 4}$ 1035-1042.

Aquila S, Sisci D, Gentile ME, Middea E, Siciliano L \& Andò S 2002 Human ejaculated spermatozoa contain active P450 aromatase. Journal of Clinical Endocrinology and Metabolism 87 3385-3390.

Aquila S, Gentile M, Middea E, Catalano S \& Andò S 2004 Autocrine regulation of insulin secretion in human ejaculated spermatozoa. Endocrinology 146 552-557.

Aquila S, Gentile M, Middea E, Catalano S, Morelli C, Pezzi V \& Andò S 2005 Leptin secretion by human spermatozoa. Journal of Clinical Endocrinology and Metabolism 90 4753-4761.

Barash IA, Cheung CC, Weigle DS, Ren H, Kabigting EB, Kuijper JL, Clifton DK \& Steiner RA 1996 Leptin is a metabolic signal to the reproductive system. Endocrinology 137 3144-3147.

Bennett BD, Solar GP, Yuan JQ, Mathias J, Thomas GR \& Matthews W 1996 A role for leptin and its cognate receptor in hematopoiesis. Current Biology 6 1170-1180.

Bjorbaek C, Elmquist JK, Michl P, Ahima RS, van Bueren A, McCall AL \& Flier JS 1998 Expression of leptin receptor isoforms in rat brain microvessels. Endocrinology 139 3485-3491.

Booth PJ, Craigon J \& Foxcroft GR 1994 Nutritional manipulation of growth and metabolic and reproductive status in pre-pubertal gilts. Journal of Animal Science 72 2415-2424. 
Booth PJ, Cosgrove JR \& Foxcroft GR 1996 Endocrine and metabolic responses to re-alimentation in feed-restricted pre-pubertal gilts: associations among gonadotropins, metabolic hormones, glucose, and utero ovarian development. Journal of Animal Science 74 840-848.

Bouloumie A, Drexler HC, Lafontan M \& Busse R 1998 Leptin, the product of Ob gene, promotes angiogenesis. Circulation Research 83 1059-1066.

Breidert M, Miehlke S, Glasow A, Orban Z, Stolte M, Ehninger G, Bayerdorffer E, Nettesheim O, Halm U, Haidan A et al. 1999 Leptin and its receptor in normal human gastric mucosa and in Helicobacter pyloriassociated gastritis. Scandinavian Journal of Gastroenterology $\mathbf{3 4}$ 954-961.

Caprio M, Fabbrini E, Isidori AM, Aversa A \& Fabbri A 2001 Leptin in reproduction. Trends in Endocrinology and Metabolism 12 65-72.

Caprio M, Fabbrini E, Ricci G, Basciani S, Gnessi L, Arizzi M, Carta AR, De Martino MU, Isidori AM, Frajese GV et al. 2003 Ontogenesis of leptin receptor in rat Leydig cells. Biology of Reproduction 68 1199-1207.

Cioffi JA, Shafer AW, Zupancic TJ, Smith-Gbur J, Mikhail A, Platika D \& Snodgrass HR 1996 Novel B219/OB receptor isoforms: possible role of leptin in hematopoiesis and reproduction. Nature Medicine 2 585-589.

Cosgrove JR, Tilton JE, Hunter MG \& Foxcroft GR 1992 Gonadotropinindependent mechanisms participate in ovarian responses to re-alimentation in feed-restricted prepubertal gilts. Biology of Reproduction $\mathbf{4 7}$ 736-745.

Cunningham MJ, Clifton DK \& Steiner RA 1999 Leptin's actions on the reproductive axis: perspectives and mechanisms. Biology of Reproduction 60 216-222.

Dieterich KD \& Lehnert H 1998 Expression of leptin receptor mRNA and the long form splice variant in human anterior pituitary and pituitary adenoma. Experimental and Clinical Endocrinology and Diabetes 106 522-525.

El-Hefnawy T, loffe S \& Dym M 2000 Expression of the leptin receptor during germ cell development in the mouse testis. Endocrinology 141 2624-2630.

Fisher HM, Brewis IA, Barratt CL, Cooke ID \& Moore HD 1998 Phosphoinositide 3-kinase is involved in the induction of the human sperm acrosome reaction downstream of tyrosine phosphorylation. Molecular Human Reproduction 4 849-855.

Flesch FM, Colenbrander B, van Golde LM \& Gadella BM 1999 Capacitation induces tyrosine phosphorylation of proteins in the boar sperm plasma membrane. Biochemical and Biophysical Research Communications 262 787-792.

Fujita Y, Murakami M, Ogawa Y, Masuzaki H, Tanaka M, Ozaki S, Nakao K \& Mimori T 2002 Leptin inhibits stress-induced apoptosis of T lymphocytes. Clinical and Experimental Immunology 128 21-26.

Galantino-Homer HL, Visconti PE \& Kopf GS 1997 Regulation of protein tyrosine phosphorylation during bovine sperm capacitation by a cyclic adenosine 3959-monophosphate-dependent pathway. Biology of Reproduction 56 707-719.

Ghilardi N \& Skoda RC 1997 The leptin receptor activates Janus Kinase 2 and signals for proliferation in a factor-depended cell line. Molecular Endocrinology 11 393-399.

Glasow A, Haidan A, Hilbers U, Breidert M, Gillespie J, Scherbaum WA, Chrousos GP \& Bornstein SR 1998 Expression of Ob receptor in normal human adrenals: differential regulation of adrenocortical and adrenomedullary function by leptin. Journal of Clinical Endocrinology and Metabolism 83 4459-4466.

Glogowski J, Demianowicz W, Piros B \& Ciereszko A 1998 Determination of acrosin activity of boar spermatozoa by the clinical method: optimization of the assay and changes during short-term storage of semen. Theriogenology $\mathbf{5 0} 861-872$.

Gordeladze JO, Drevon CA, Syversen U \& Reseland JE 2002 Leptin stimulates human osteoblastic cell proliferation, de novo collagen synthesis, and mineralization: impact on differentiation markers, apoptosis, and osteoclastic signalling. Journal of Cellular Biochemistry 85 825-836.

Gregoraszczuk EL, Ptak A, Wojtowicz AK, Gorska T \& Nowak KW 2004 Estrus cycle-dependent action of leptin on basal and GH or IGF-I stimulated steroid secretion by whole porcine follicles. Endocrine Regulations 38 15-21.

Ito T, Deng X, Carr BK \& May WS 1997 Bcl-2 phosphorylation required for anti-apoptosis function. Journal of Biological Chemistry 272 11671-11673.
Jope T, Lammert A, Kratzsch J, Paasch U \& Glander HJ 2003 Leptin and leptin receptor in human seminal plasma and in human spermatozoa. International Journal of Andrology 26 335-341.

Kalab P, Peknicova J, Geussova G \& Moos J 1998 Regulation of protein tyrosine phosphorylation in boar sperm through a cAMP-dependent pathway. Molecular Reproduction and Development 51 304-314.

Kamohara S, Burcelin R, Halaas JL, Friedman JM \& Charron MJ 1997 Acute stimulation of glucose metabolism in mice by leptin treatment. Nature 389 374-377.

Kuster CE, Hess RA \& Althouse GC 2004 Immunofluorescence reveals ubiquitination of retained distal cytoplasmic droplet on ejaculated porcine spermatozoa. Journal of Andrology 25 340-347.

Lackey BR, Gray SL \& Henricks DM 2002 Measurement of leptin and insulin-like growth factor-I in seminal plasma from different species. Physiological Research 51 309-311.

de Lamirande E \& Gagnon C 2002 The extracellular signal-regulated kinase (ERK) pathway is involved in human sperm function and modulated by the superoxide anion. Molecular Human Reproduction 81 24-35.

De Lamirande E, Leclerc P \& Gagnon C 1997 Capacitation as a regulatory event that primes spermatozoa for the acrosome reaction and fertilization. Molecular Human Reproduction 3 175-194.

Leclerc P, de Lamirande E \& Gagnon C 1996 Cyclic adenosine 39,59 monophosphate dependent regulation of protein tyrosine phosphorylation in relation to human sperm capacitation and motility. Biology of Reproduction 55 684-692.

Leclerc P, de Lamirande E \& Gagnon C 1998 Interaction between $\mathrm{Ca}^{2+}$, cyclic $3^{\prime}, 5^{\prime}$ adenosine monophosphate, the superoxide anion, and tyrosine phosphorylation pathways in the regulation of human sperm capacitation. Journal of Andrology 19 434-443.

Lee GH, Proenca R, Montez JM, Carroll KM, Darvishzadeh JG, Lee JI \& Friedman JM 1996 Abnormal splicing of the leptin receptor in diabetic mice. Nature 379 632-635.

Lin J, Barb CR, Matteri RL, Kraeling RR, Chen X, Meinersman RJ \& Rampacek GB 2000 Long for leptin receptor mRNA expression in the brain, pituitary and other tissues in the pig. Domestic Animal Endocrinology 19 53-61.

Lollmann B, Gruninger S, Stricker-Krongrad A \& Chiesi M 1997 Detection and quantification of the leptin receptor splice variants OBRa, b, and, e in different mouse tissues. Biochemical and Biophysical Research Communications 238 648-652.

Lord GM, Matarese G, Howard JK, Baker RJ, Bloom SR \& Lechler RI 1998 Leptin modulates the T-cell immune response and reverses starvationinduced immunosuppression. Nature 394 897-901.

Luconi M, Barni B, Vannelli GB, Krausz C, Marra F, Benedetti PA, Evangelista V, Francavilla S, Properzi G, Forti G et al. 1998 Extracellular signal-regulated kinases modulate capacitation of human spermatozoa. Biology of Reproduction 58 1476-1489.

Luconi M, Marra F, Gandini L, Filimberti E, Lenzi A, Forti G \& Baldi E 2001 Phosphatidylinositol 3-kinase inhibition enhances human sperm motility. Human Reproduction 16 1931-1937.

Margetic S, Gazzola C, Pegg GG \& Hill RA 2002 Leptin: a review of its peripheral actions and interactions. International Journal of Obesity and Related Metabolic Disorders 26 1407-1433.

Miller D 2000 Analysis and significance of messenger RNA in human ejaculated spermatozoa. Molecular Reproduction and Development 56 259-264.

Muller G, Ertl J, Gerl M \& Preibisch G 1997 Leptin impairs metabolic actions of insulin in isolated rat adipocytes. Journal of Biological Chemistry 272 10585-10593.

Murakami T, Yamashita T, lida M, Kuwajima M \& Shima K 1997 A short form of leptin receptor performs signal transduction. Biochemical and Biophysical Research Communications 231 26-29.

Naz RK, Ahmad K \& Kaplan P 1992 Expression and function of ras protooncogene proteins in human sperm cells. Journal of Cell Science $\mathbf{1 0 2}$ 487-494.

Okuya S, Tanabe K, Tanizawa Y \& Oka Y 2001 Leptin increases the viability of isolated rat pancreatic islets by suppressing apoptosis. Endocrinology 142 4827-4830.

Quesnel H \& Prunier A 1995 Endocrine bases of lactational anoestrus in the sow. Reproduction, Nutrition, Development 35 395-414. 
Rossetti L, Massillon D, Barzilai N, Vuguin P, Chen W, Hawkins M, Wu J \& Wang J 1997 Short term effects of leptin on hepatic gluconeogenesis and in vivo insulin action. Journal of Biological Chemistry 272 27758-27763.

Shadan S, James PS, Howes EA \& Jones R 2004 Cholesterol efflux alters lipid raft stability and distribution during capacitation of boar spermatozoa. Biology of Reproduction 71 253-265.

Sierra-Honigmann MR, Nath AK, Murakami C, Garcia-Cardena G, Papapetropoulos A, Sessa WC, Madge LA, Schechner JS, Schwabb MB, Polverini PJ et al. 1998 Biological action of leptin as an angiogenic factor. Science 281 1683-1686.

Soyupek S, Armagan A, Serel TA, Hoscan MB, Perk H, Karaoz E \& Candir O 2005 Leptin expression in the testicular tissue of fertile and infertile men. Archives of Andrology 51 239-246.

Takaya K, Ogawa Y, Isse N, Okazaki T, Satoh N, Masuzaki H, Mori K, Tamura N, Hosoda K \& Nakao K 1996 Molecular cloning of rat leptin receptor isoform complementary DNAs-identification of a missense mutation in Zucker fatty $(\mathrm{fa} / \mathrm{fa})$ rats. Biochemical and Biophysical Research Communications 225 75-83.

Tardif S, Cubè C \& Bailey JL 2003 Porcine sperm capacitation and tyrosine kinase activity are dependent on bicarbonate and calcium but protein tyrosine phosphorylation is only associated with calcium. Biology of Reproduction 68 207-213.

Tartaglia LA 1997 The leptin receptor. Journal of Biological Chemistry 272 6093-6096.

Tartaglia LA, Dembski M, Weng X, Deng N, Culpepper J, Devos R, Richards GJ, Campfield LA, Clark FT, Deeds J et al. 1995 Identification and expression cloning of a leptin receptor, OB-R. Cell 83 1263-1271.

Tena-Sempere $\mathbf{M}$ \& Barreiro ML 2002 Leptin in male reproduction: the testis paradigm. Molecular and Cellular Endocrinology 188 9-13.

Tena-Sempere M, Manna PR, Zhang FP, Gonzalez LC, Dieguez C, Huhtaniemi I \& Aguilar E 2001 Molecular mechanism of leptin action in adult rat testis: potential targets for leptin-induced inhibition of steroidogenesis and pattern of leptin receptor messenger ribonucleic acid expression. Journal of Endocrinology 170 413-423.

Thomas T 2004 The complex effects of leptin on bone metabolism through multiple pathways. Current Opinion in Pharmacology 4 295-300.

Tsiaoussis J, Newsome PN, Nelson LJ, Hayes PC \& Plevris JN 2001 Which hepatocyte will it be? Hepatocyte choice for bioartificial liver support systems Liver Transplantation 7 2-10.

Uotani S, Bjorbaek C, Tornoe J \& Flier JS 1999 Functional properties of leptin receptor isoforms: internalization and degradation of leptin and ligand-induced receptor downregulation. Diabetes 48 279-286.
Vilei MT, Granato A, Ferraresso C, Neri D, Carraro P, Gerunda G \& Muraca M 2001 Comparison of pig, human and rat hepatocytes as a source of liver specific metabolic functions in culture systems implications for use in bioartificial liver devices. International Journal of Artificial Organs 24 392-396.

Visconti PE, Bailey JL, Moore GD, Pan D, Olds-Clarke P \& Kopf GS 1995 Capacitation of mouse spermatozoa. I. Correlation between the capacitation state and protein tyrosine phosphorylation. Development 121 1129-1137.

Visconti PE, Galantino-Homer H, Ning X, Moore GD, Valenzuela JP, Jorgez CJ, Alvarez JG \& Kopf GS 1999a Cholesterol efflux-mediated signal transduction in mammalian sperm. b-cyclodextrins initiate transmembrane signalling leading to an increase in protein tyrosine phosphorylation and capacitation. Journal of Biological Chemistry 274 3235-3242.

Visconti PE, Ning X, Fornes MW, Alvarez JG, Stein P, Connors SA \& Kopf GS $1999 \mathrm{~b}$ Colesterol efflux-mediated signal transduction in mammalian sperm: cholesterol release signals an increase in protein tyrosine phosphorylation during mouse sperm capacitation. Developmental Biology 214 429-443.

Yamashita T, Murakami T, Otani S, Kuwajima M \& Shima K 1998 Leptin receptor signal transduction: OBRa and OBRb of fa type. Biochemical and Biophysical Research Communications 246 752-759.

Yaspelkis BB III, Ansari L, Ramey EL, Holland GJ \& Loy SF 1999 Chronic leptin administration increases insulin-stimulated skeletal muscle glucose uptake and transport. Metabolism 48 671-676.

Zak LJ, Cosgrove JR, Aherne FX \& Foxcroft GR 1997 Pattern of feed intake and associated metabolic and endocrine changes differentially affect post weaning fertility in primiparous lactating sows. Journal of Animal Science 75 208-211.

Zhao AZ, Bornfeldt KE \& Beavo JA 1998 Leptin inhibits insulin secretion by activation of phosphodiesterase 3B. Journal of Clinical Investigation $\mathbf{1 0 2}$ 869-873.

Zurek E, Foxcroft GR \& Kennelly JJ 1995 Metabolic status and interval to first ovulation in postpartum dairy cows. Journal of Dairy Science $\mathbf{7 8}$ 1909-1920.

Received 29 June 2007

First decision 27 July 2007

Revised manuscript received 29 February 2008

Accepted 20 March 2008 